FIU Law Review

Spring 2010

\title{
The Role of the Judiciary When the Agency Confirmation Process Stalls: Thoughts on the Two-Member NLRB and the Questions the Supreme Court Should Have, But Didn't, Address in New Process Steel, L.P. v. NLRB
}

Catherine L. Fisk

University of California, Irvine

Follow this and additional works at: https://ecollections.law.fiu.edu/lawreview

Part of the Other Law Commons

Online ISSN: 2643-7759

Recommended Citation

Catherine L. Fisk, The Role of the Judiciary When the Agency Confirmation Process Stalls: Thoughts on the Two-Member NLRB and the Questions the Supreme Court Should Have, But Didn't, Address in New Process Steel, L.P. v. NLRB, 5 FIU L. Rev. 593 (2010).

DOI: https://dx.doi.org/10.25148/lawrev.5.2.15

This Article is brought to you for free and open access by eCollections. It has been accepted for inclusion in FIU Law Review by an authorized editor of eCollections. For more information, please contact lisdavis@fiu.edu. 


\title{
The Role of the Judiciary When the Agency Confirmation Process Stalls: Thoughts on the Two-Member NLRB and the Questions the Supreme Court Should Have, But Didn't, Address in New Process Steel, L.P. v. NLRB
}

\author{
Catherine L. Fisk ${ }^{*}$
}

\section{INTRODUCTION}

The National Labor Relations Board, by statute, has five members who serve staggered five-year terms. ${ }^{1}$ It operated with two of the five members from January 1, 2008 to March 27, 2010 because the Senate did not confirm nominees to replace three members whose terms expired. ${ }^{2}$ President Obama made recess appointments to the Board effective March 27, 2010, and the delegation expired. ${ }^{3}$ In dozens of cases, employers resisting compliance with Board orders challenged the validity of the NLRB's decisions on the ground that the Board lacks the authority to act with only two members. ${ }^{4}$ Five courts of appeals held the Board has power to act with two members. ${ }^{5}$ The D.C. Circuit held that it does not. ${ }^{6}$ The

\footnotetext{
* Catherine L. Fisk is Chancellor's Professor of Law at University of California, Irvine. Professor Fisk is grateful to Deborah Malamud, William Gould, and participants at the Florida International University College of Law symposium on the 75th anniversary of the National Labor Relations Act for discussing the ideas contained here and to Christina Tsou and Jackie Woodbridge for research assistance. The author claims responsibility for errors.

29 U.S.C. $\S 153(a)$.

2 See Talk about Recess Appointments Follows Senate's Defeat of Cloture Motion on Becker, 30 Daily Lab. Rep. (BNA) at A-10 (Feb. 17, 2010).

3 Letter Brief from Elena Kagan, Solicitor General, U.S. Department of Justice, to William K. Suter, Clerk, Supreme Court of the United States (Apr. 26, 2010) at 1 (on file with the Supreme Court of the United States).

4 As of November 2009, the two-member Board's authority had been challenged in approximately 77 cases pending in the courts of appeals. See Brief for the National Labor Relations Board at 6 n.7, New Process Steel, L.P. v. NLRB, No. 08-1457, slip op. (U.S. June 17, 2010) (citing "We're Poised for Changes" in Labor Law, Chairman Liebman Says at ABA Conference, (volume \#?) Daily Lab. Rep. (BNA). at C-3 (Nov. 12, 2009)).

5 Ne. Land Servs., Ltd. v. NLRB, 560 F.3d 36, 41 (1st Cir. 2009); Snell Island SNF LLC v. NLRB, 568 F.3d 410, 424 (2d Cir. 2009); Narricot Indus., L.P. v. NLRB, 587 F.3d 654, 660 (4th Cir. 2009); New Process Steel, L.P. v. NLRB, 564 F.3d 840, 845-46 (7th Cir. 2009); Teamsters Local Union No. 523 v. NLRB, 590 F.3d 849, 852 (10th Cir. 2009).

6 Laurel Baye Healthcare by Lanier v. NLRB, 564 F.3d 469 (D.C. Cir. 2009).
} 
Supreme Court divided 5 to 4 and held that it did not, though on slightly different reasons than the D.C. Circuit.

The underlying politics of the issue reflect the labor-management split, as does so much of contemporary labor law. Generally, labor was on the side of upholding the power of the two-member Board and management was on the side of invalidating it. At the Supreme Court, the four most conservative Justices took the management side, three of the four most liberal took the labor side. Kennedy sided with the liberals and Stevens sided with the conservatives. Other than Stevens' position, the political orientation of those on both sides of the issue was not surprising, because most of the nearly 600 decisions rendered by the two-member Board ${ }^{8}$ involved unfair labor practices committed by employers. ${ }^{9}$ Because employers have the option of going to court to seek remedies for the most substantial harms that unions can inflict on them (secondary boycotts) ${ }^{10}$ much of the work of the Board (although certainly not all of it) consists of unfair labor practice cases brought by employees or unions against employers and in representation proceedings in which the union is seeking recognition.

Both the majority and dissenting opinions of the Supreme Court, like that of all six circuit courts, focused on the language of the statute, which consists of four separate clauses governing the power of the Board members to delegate their authority to subgroups of the members, the quorum, and the effect of vacancies. The difference of opinion was whether the quorum requirement trumps the others, or whether an exception trumps the quorum requirement. Four members of the Board, the Office of Legal Counsel, and five courts of appeals sided with the dissent. A contrary reading by the five Justices in the majority and one court of appeals carried the day. Quite frankly, I think it's close to preposterous to pretend that the language of the statute by itself can resolve the debate. The whole episode illustrates the trouble with plain language interpretations of the statute: in this case, as the Court majority admitted, the various readings of the statute offered by the majority, the dissent, and the courts of appeals are "textually permissible," and the difference among them really is over which reading is most "plausible," which requires a form of functional and policy analysis that is conspicuously absent in the cases. ${ }^{11}$

\footnotetext{
7 New Process Steel, L.P. v. NLRB, No. 08-1457, slip op. (U.S. June 17, 2010).

8 See id. at 3 (citing an April 2010 letter brief from the Solicitor General to the U.S. Supreme Court reporting that during the period in which the Board had only two members, it decided almost 600 cases).

See Annual Report of NLRB.

1029 U.S.C. $\$ 187$ (2010).

11 New Process Steel, No. 08-1457, slip op. at 3 (Kennedy, J., dissenting); see also infra text accompanying note 4 .
} 
Finding the statutory language, the legislative history and Chevron deference insufficient to answer the question, this article explores what courts should do when a failure to nominate or confirm replacements threatens to render an agency incapable of enforcing the law. An enduring question is what role courts should play when the nomination and confirmation process threatens to prevent an agency from acting at all. This is a pressing issue across the administrative state, as the number of vacancies in federal agencies is very substantial. ${ }^{12}$ The Supreme Court did not address this issue, but the real question - and it is a hard question - concerns the role of courts in intervening to keep agencies functioning when the nomination process fails. Parsing the language of the statute, as the Court did, does not answer the question. But until the Court is prepared to offer a thoughtful analysis of the role of the judiciary in instances of administrative law melt-down, we will have to wait for answers to the real questions at stake in the case.

\section{The LEgAL AND POLITICAL CONTEXT}

\section{A. Background}

The Wagner Act created the NLRB with three members in $1935 .^{13}$ In 1947, the Taft-Hartley Act expanded the membership of the Board to five. ${ }^{14}$ The 1935 Act provided that two members of the Board constituted a quorum, and allowed the Board to delegate its authority to two members to act. $^{15}$ Between 1935 and 1947, during three separate periods when the Board had a vacancy, the two remaining members issued a total of 466 decisions. ${ }^{16}$ When the membership of the Board was expanded in 1947, the quorum was increased to three, but the statute stated that the Board was authorized to delegate "any or all" of its authority "to any group of three or more members," two members of which would constitute a quorum. ${ }^{17}$ That provision remains in the statute today, and the Board decides a very sub-

12 See Anne Joseph O'Connell, Vacant Offices: Delays in Staffing Top Agency Positions, 82 S. CAL. L. REV. 913 (2009) (describing the increasing length of vacancies of agency positions).

13 Wagner Act, ch. 372, § 3(a)-(b), 49 Stat. 449 (1935) (current version at 29 U.S.C. $\S \S 151-169$ (2006)).

14 Taft-Hartley Act, ch. 120, § 3(a), 61 Stat. 136 (1947) (current version at 29 U.S.C. $\S ~ 141-144$, 167, 171-175, 175(a), 176-183, 185-187).

15 Wagner Act $\S 3(\mathrm{~b})$.

16 Between August 27 and October 11, 1941, the Board had only two members and issued 224 decisions. Between August 27 and November 26, 1940, the Board had only two members and issued 239 decisions. And between August 31 and September 23, 1936, the Board had only two members and issued 3 decisions. See Snell Island SNF LLC, 568 F.3d at 422 (quoting Brief of NLRB at 16-17 n.8).

17 Taft-Hartley Act, § 3(b). 
stantial number of its cases through three-member panels. ${ }^{18}$ The Court held in New Process Steel that although the full Board can delegate its powers to three members under the first sentence and two members can exercise the delegated powers to two under the last clause of the second sentence, the power of two members to decide expires when one of the delegee group leaves the Board. ${ }^{19}$

The NLRB, of course, is not alone in facing problems associated with the agency being potentially unable to act because the terms of members have expired and the number of remaining members has become less than a majority of the total number of statutorily authorized memberships. Indeed, the NLRB's membership, vacancy, and quorum provisions are typical of those of other agencies commonly denominated as "independent." 20 The NLRB, like many independent agencies, has an odd number of members who serve fixed, staggered terms such that the term of a member is longer than the term of the president. ${ }^{21}$ It has been said that " $[\mathrm{t}]$ his organizational structure is intended to dilute the effect of transitory political events on agency policy, which underscores the agencies' independent role." ${ }^{22}$ Some statutes require political balance, ${ }^{23}$ whereas others (including the NLRB) have adopted political balance as a matter of tradition even though it is not statutorily mandated. ${ }^{24}$

Ever since Congress created the Interstate Commerce Commission and provided that a vacancy shall not impair the power of the Commission to act, many subsequent statutes creating other agencies have contained a similar provision, and one exists in the NLRA. ${ }^{25}$ Agencies and reviewing

18 See Annual Report of NLRB.

19 New Process Steel, No. 08-1457, slip op. at 4, 13.

20 See Marshall J. Berger \& Gary J. Edles, Established by Practice: The Theory and Operation of Independent Federal Agencies, 52 ADMIN. L. REV. 1111, 1139, 1182 (2000) (describing the NLRA's provisions for appointments of members and for a quorum of the agency as typical).

21 Id. at 1137 (describing the typical multi-member administrative agency as having, like the Interstate Commerce Commission, an odd number of members who serve fixed, staggered terms that typically extend beyond the term of the appointing president).

22 Id.

23 Id. at 1139 ("Typically, agency statutes require political balance, i.e., no more than a bare majority of members of multi-member agencies may come from the same political party." (noting that the NLRB is an exception to this rule)).

24 See 29 U.S.C. § 153(a) (2006) (making no mention of political balance of Board membership). The custom is that three members reflect the president's views on labor policy and two represent those of the other party. See James J. Brudney, Isolated and Politicized: The NLRB's Uncertain Future, 26 COMP. LAB. L. \& POL'Y J. 221, 243-52 (2005). Other agencies that are not statutorily required to have political balance are the Occupational Safety and Health Review Commission and the Federal Mine Safety and Health Review Commission. 29 U.S.C. § 661(a) (2006) (OSHRC); 30 U.S.C. § 823(a) (2006) (FMSHRC); see also Berger \& Edles, supra note 20, at 1139.

25 See Breger \& Edles, supra note 20, at 1135; Interstate Commerce Act, ch. 104, § 11, 24 Stat. 379, 383 (1887); 29 U.S.C. § 153(b). 
courts have generally concluded that an agency has power to continue acting when its membership falls, at least where the enabling statute has a provision like the NLRA's providing that a vacancy shall not affect the power of the remaining members to act. ${ }^{26}$ The hard question is whether an agency can continue to act when its membership falls below the majority of the statutorily authorized full size. The Securities Exchange Commission dealt with the risk that it would lose authority to act when its membership fell below the majority of five by adopting a 1995 regulation providing that three members constitute a quorum unless the number of members in office is fewer than three, in which case the quorum is the number of members in office. $^{27}$ The Federal Trade Commission has experimented with a number of strategies to deal with the possibility of vacancies depriving it of the power to act. ${ }^{28}$ In 1976, the FTC determined that two of its statutory five members could issue a ruling "when three exist and are aware of the action," and, more recently, adopted a rule defining a quorum as "a majority of the members of the commission in office and not recused from participating in the matter." ${ }^{29}$ The justification for the new rule is the desire to permit the FTC to act in cases "where, due to vacancies, recusals, or a combination of the two, fewer than three commissioners can participate.,"30 Even where there is no such explicit provision, courts have found that as a matter of sensible administration the vacancy of a majority of seats does not deprive the agency of the power to act. ${ }^{31}$ As the Supreme Court noted, federal courts of appeals delegate to three-judge panels the power to decide cases, and the death or retirement of one member of the three-judge panels

26 See infra note 31.

2717 C.F.R. $\$ 200.41$ (1999). The D.C. Circuit upheld the power of the SEC to adopt this rule in Falcon Trading Group Ltd. v. SEC, 102 F.3d 579, 582 (D.C. Cir. 1996), reasoning that the SEC was empowered by Congress to create its rule.

28 Kelly M. Falls, A Quorum of One: Redefining Recusal Standards in the Federal Trade Commission, 19 GeO. J. Legal ETHics 705, 710-11 (2006).

29 Id.

$30 \quad I d$. at 710.

31 See Assure Competitive Transp., Inc. v. United States, 629 F.2d 467, 472-74 (7th Cir. 1980) (holding that the Interstate Commerce Commission had the power to act even though its membership had fallen to five of eleven authorized positions); see also R.R. Yardmasters of Am. v. Harris, 721 F.2d 1332, 1333-34 (D.C. Cir. 1983) (upholding the power of the National Mediation Board to act with only one of its three members in order to prevent the complete disability of the agency because of vacancies); McLauglin v. Union Oil Co., 869 F.2d 1039, $1041-42$ (7th Cir. 1989) (upholding a provision of the enabling statute of the Occupational Safety and Health Review Commission providing that an administrative law judge's decision goes into effect unless a commission member directs otherwise, even where the OSHRC had no quorum). 
does not divest the panel of the power to act. ${ }^{32}$ But the Court reached a different result for the NLRA.

\section{B. Language of the NLRA}

As illustrated by the 5-4 split on the Supreme Court and the diversity of interpretations offered by the six courts of appeals to address the issue, as well as the opinion of the Office of Legal Counsel, there are plausible interpretations of the NLRA to support both that the language of section 3(b) does allow the two-member Board to act and that it does not. ${ }^{33}$ The First Circuit found it plain that it does ${ }^{34}$ (and the Seventh Circuit agreed ${ }^{35}$ ). In the Supreme Court, the employer seeking to invalidate the work of the twomember Board and its amici find the language plain in one direction ${ }^{36}$ and the United States and its amici find it plain in the other. ${ }^{37}$ The one article by a law professor on the issue finds the D.C. Circuit's to be "the best plainmeaning reading of the statute." 38 For the reasons explained below, there are plausible plain meaning arguments on both sides of the issue, and any judgment about whether one is better than another is more likely to turn on one's view about the merits than on syntax.

Section 3(b) reads:

The Board is authorized to delegate to any group of three or more members any or all of the powers which it may itself exercise. A vacancy in the Board shall not impair the right of the remaining members to exercise all of the powers of the Board, and three members of the Board shall, at all times, constitute a quorum of the board, except that two members shall constitute a quorum of any group designated pursuant to the first sentence hereof.

This paragraph can be divided into four clauses: (1) the delegation clause; (2) the vacancy clause; (3) the quorum clause; and (4) the exception

32 New Process Steel, L.P. v. NLRB, No. 08-1457, slip op. at 11 (June 17, 2010) (quoting 28 U.S.C. § 46(b) and Nguyen v. United States, 539 U.S. 69, 82 (2003)).

33 Laurel Baye Healthcare v. NLRB, 564 F.3d 469, $472-73$ (D.C. Cir. 2009); Ne. Land Servs. v. NLRB, 560 F.3d 36, 41 (1st Cir. 2009).

34 Ne. Land Servs., 560 F.3d at 41.

35 New Process Steel, L.P. v. NLRB, 564 F.3d 840, 845-46 (7th Cir. 2009), rev'd, No. 08-1457, slip op. at 11 (June 17, 2010).

36 Brief for Petitioner, New Process Steel, L.P. at 16, New Process Steel, No. 08-1457 (Dec. 23, 2009).

Brief for National Labor Relations Board at 14, New Process Steel, No. 08-1457 (Feb. 2, 2010).

38 Ronald Turner, On the Authority of the Two-Member NLRB: Statutory Interpretation Approaches and Judicial Choices, 27 HofSTRA LAB. \& EMP. L.J. 13, 45 (2009).

3929 U.S.C. $\S 153$ (b) (2006). 
clause. The difference between the majority and the dissent was in which clauses should be read to take primacy over the others.

The Supreme Court majority and the D.C. Circuit found the general quorum clause - the second clause of the second sentence ("three members of the Board shall, at all times, constitute a quorum of the Board") - to be decisive. They read the exception clause ("except that two members shall constitute a quorum") to allow two members to act for the Board only when it has three members. ${ }^{40}$ They read the vacancy clause and the exception clause to be subordinate to the quorum clause.

The Supreme Court majority offered several textual reasons for its conclusion. First, to allow a group of two to act for the Board would allow "two members to act as the Board ad infinitum, which dramatically undercuts the significance of the Board quorum requirement by allowing its permanent circumvention." 41 To allow the Board to act indefinitely with only two members would, in the majority's view, undermine the general principle that three is a quorum. Second, the majority reasoned that if Congress had intended to allow the Board to operate with only two members, it would have explicitly said so. ${ }^{42}$ And, third, the vacancy clause means only that vacancies do not affect "the powers of the Board"; it does not mean that vacancies do not affect powers of a "group" delegated by the Board's powers. $^{43}$ This last point was the one emphasized by New Process Steel. It had relied on the D.C. Circuit's focus on the "at all times," language but added a new emphasis, arguing that "the vacancy clause refers only to the "Board" itself and not to "any group of three or more members. . . . The quorum clauses and the vacancy clause easily live in harmony when the vacancy clause is applied, as it is written, only to the Board." ${ }^{44}$ In addition, New Process argued that the vacancy clause means that "[a] vacancy in a three-member group precludes any action by that group unless the missing member is replaced," because the group is "no longer fully constituted and therefore no longer a proper delegee." "45 "This argument places emphasis on the term "group": a quorum of two is permissible only when there is a "group" of three. When the "group" of three who receives the delegation ceases to exist, then the power of the remaining two disappears.

40 New Process Steel, No. 08-1457, slip op. at 6; Laurel Baye Healthcare v. NLRB, 564 F.3d 469, 472-73 (D.C. Cir. 2009).

41 New Process Steel, No. 08-1457, slip op. at 6.

42 Id. at 7.

43 Id. at 11 .

44 Brief for Petitioner New Process Steel, L.P. at 19-20, New Process Steel, No. 08-1457 (Dec. 23, 2009).

45 Id. at $21-22,24$ n. 10 . 
Finally, the majority rejected one significant part of the reading of section 3(b) that had been adopted by the D.C. Circuit. The D.C. Circuit had concluded that the invalidity of a delegation of Board authority to a two-member group also applied to the Board's delegation of authority to any other entity within the Board, which would cast doubt on the powers that the Board had delegated to the Regional Directors and General Counsel. The majority rejected this reading, concluding only that the two members could not decide cases, and saying its holding "does not cast doubt on" the delegations to the Regional Directors and General Counsel. ${ }^{46}$

In contrast, the four dissenting Justices, along with the First, Second, Fourth, Seventh, and Tenth Circuits, as well as the Office of Legal Counsel, found that the language of section 3(b) leads to the opposite conclusion. The dissent explained that a reading of section 3(b) that allowed the agency to function with two members was not only the one most consistent with the purpose of the statute and the orderly operation of the agency but also was the textually preferable one.

The dissent read the four clauses of section 3(b) as had all the circuit courts except the D.C. Circuit. The delegation clause (the first sentence of section 3(b)) allows the Board to delegate its authority to a group of three. The vacancy clause says that vacancies shall not affect the power of the remaining members. And the exception clause trumps the quorum clause in providing that two members of the Board constitute a quorum when the Board has delegated its authority to a group of three. ${ }^{47}$ This last point was the one emphasized in the briefs of the government and the AFL-CIO, as amicus in support of the NLRB. As the AFL-CIO's brief put it, "when the Board has delegated all of its powers to a designated three-member group and later vacancies reduce the Board's complement to two of the three members of that designated group, those remaining members constitute a quorum of the group with the right unimpeded by the vacancies to exercise all of the delegated Board power." States argued that "Congress has used the construction 'at all times . . . except' in a number of statutes to accomplish exactly what it did in Section 3(b) - to provide that a general rule should apply at all times except in the instances specified by Congress in the statute."49

\footnotetext{
46 New Process Steel, No. 08-1457, slip op. at 9 n.4.

47 See id. at 9-12; see also Ne. Land Servs., Ltd., v. NLRB, 560 F.3d 36, 41 (1st Cir. 2009); New Process Steel, L.P. v. NLRB, 564 F.3d 840, 846 (7th Cir. 2009).

48 Brief for American Federation of Labor and Congress of Industrial Organizations as Amicus Curiae Supporting Respondent at 5, New Process Steel, No. 08-1457, 2010 WL 581624.

49 Brief for Respondent at 18 \& n.13, New Process Steel, No. 08-1457, 2010 WL 383618 (citing three statutory examples, including the 2008 Higher Education Opportunity Act, a statute governing
} 
The dissent offered a Black's Dictionary definition of the meaning of the term quorum to explain why the quorum clause should not be read to require the Board to have three members for a delegation to remain valid. Although the dissent did not phrase the point precisely this way, the government's brief had emphasized that the ordinary meaning of the term quorum is the number of officers or members of a body who must participate for a body to act (a "participation floor"). ${ }^{50}$ The majority's interpretation, which was the one offered by the employer, was that the quorum clause was the number of members a body must have in order for it to act (a "membership floor").

The dissent then offered a number of reasons why the quorum clause should not trump the vacancy clause and the exception clause. First, the dissent saw no reason to read the quorum clause to allow two members to decide cases only when the third member was not participating because of recusal or illness and not when the third position was vacant. Noting the practice of federal courts to allow two judges to decide a case when the third judge on the panel has left the court, the dissent pointed out that quorum rules usually govern the number of people who must be participating to decide a matter and do not govern the number of people who must be on the body. Second, the dissent faulted the majority's reading of the text of the vacancy clause: "[U]nder the Court's reading, vacancies in the Board will often impair the right of the remaining members to exercise the powers of the Board, notwithstanding the explicit statutory command to the contrary." ${ }^{, 51}$ And, third, the majority misread the delegation clause to allow delegee groups to operate only so long as all members of the delegee group remain on the Board; in the dissent's view, the delegation clause establishes only what is required for delegation (that three members vote to delegate) and not what happens once a vacancy occurs in the delegee group. ${ }^{52}$

The final textual point raised by the dissent addresses the reading of the statute emphasized by the D.C. Circuit and offered by the employer but rejected by the majority in a footnote: does the language of the quorum clause, stating that "at all times" a quorum of the Board is three, mean that none of the Board's delegations, including to the Regional Directors and the General Counsel, were valid once the membership fell to two? As the Fourth Circuit read the statute, the exception clause is an exception to the

\footnotetext{
VISTA volunteers, and a Proclamation requiring the flags of the fifty United States to be flown at the Washington Monument at all times except when the weather is inclement).

50 Brief for Respondent at 19, New Process Steel, No. 08-1457.

51 New Process Steel, No. 08-1457, slip op. at 6-7 (Kennedy, J., dissenting).

52 Id. at 7.
} 
"at all times" language on which the D.C. Circuit placed so much emphasis. $^{53}$

The fundamental points of disagreement between the majority's and the dissent's plain language arguments are thus two. First: is the threemember quorum a "participation floor" or a "membership floor"? Second: does the "at all times" language apply to all of the Board's operations, or is the exception clause an exception to the "at all times" language of the quorum clause? The dissent read the vacancy clause and the exception clause to trump the three-member quorum rule. The majority read the three-member quorum clause to trump the vacancy clause and the "exception" clause.

\section{Legislative History}

As noted above, when the Board had only three members under the Wagner Act, a quorum was two, and two members were authorized to conduct business. When the membership of the Board was expanded to five, the quorum was increased to three, but the agency was authorized to delegate decisionmaking to groups of three and two was sufficient to constitute a quorum of a delegee group. All litigants agreed that the purpose of expanding the size of the Board was to enable it to sit in panels of three and to decide more cases. The question is whether, in the name of increased productivity, the Board can continue to act when its membership falls below some number. As to that, readings of the legislative history predictably differed. The majority insisted that when Congress increased the membership of the Board from three to five, it increased the quorum from two to three, and thus intended to require the Board to have three members in order to decide cases. ${ }^{54}$ The dissent argued that Congress intended in TaftHartley to preserve the past practice under which two members of the Board could decide cases because it did not eliminate the provision allowing delegations to groups of three which, under past practice, could decide cases by two members when a vacancy occurred in the third position. ${ }^{55}$

Litigants in the lower courts emphasized two additional provisions, although most of this was not discussed in the Supreme Court's opinions. First, some arguments have been made about the significance of the fact that the Senate version of the 1947 amendment would have increased the size of the Board to seven, four of which would constitute a quorum, but

53 Narricot Indus., L.P. v. NLRB, 587 F.3d 654, 659-60 (4th Cir. 2009).

54 New Process Steel, No. 08-1457, slip op. at 12.

55 Id. at 11 (Kennedy, J., dissenting). 
that version of the bill also authorized the Board to delegate its powers "to any group of three or more members," two of whom would constitute a quorum. As the Second Circuit explained, this provision does not directly address the question whether the Board can continue to act when its membership falls to two. The other provision of the legislative history is Senator Mahoney's statement on the Senate floor opposing an override of Truman's veto of the Act. Mahoney said:

Observe that the Board is given complete and plenary power to delegate any or all of its power to any group of three; and then any two members of that group of three can speak for the Board. So we have a bill - and I invite the attention of lawyers in this body to this - which not only authorizes the Board to delegate its powers, but authorizes the Board to delegate its powers, and all of them, to less than a quorum of the Board. ${ }^{56}$

In discussing this bit of legislative history, the Second Circuit expressed "reluctan[ce] to draw much significance from a lone remark by a single senator opposing a bill., 57

Only two of the courts of appeals discussed the legislative history. The Second Circuit found it inconclusive, other than evidencing the desire to enable the Board to operate more efficiently. Similarly, the Seventh Circuit said that, "to the extent that the legislative history points either way ... it establishes that Taft-Hartley created a body that was allowed to operate in panels in order to work more efficiently." that no authoritative legislative history addressed the precise question of whether a two-member Board can operate.

The majority and the dissent, along with the litigants, made competing arguments about the significance of the Board's past practice about two members deciding cases. Obviously, when the panel splits two to one, the rule is that stated by the two. As the majority acknowledge, when one member of a three member panel is recused from participation or decision in a case, the remaining two decide the case. ${ }^{59}$ But the majority emphasized that in the past when one member had resigned from the Board, the Board had reconstituted all the three-member panels of which the departing member had been a part rather than permit the remaining two to decide the cases. ${ }^{60}$ Similarly, the majority emphasized that Board's previous practice

\footnotetext{
5693 CONG. REC. 7523, 7525 (June 23, 1947), reprinted in 2 NLRB LEGISLATIVE HiSTORY 1629, 1632 (1948).

57 Snell Island SNF, LLC v. NLRB, 568 F.3d 410, 422 (2d Cir. 2009).

58 New Process Steel, L.P. v. NLRB, 564 F.3d 840, 847 (7th Cir. 2009).

59 New Process Steel, No. 08-1457, slip op. at 7.

$60 \quad I d$.
} 
had been for the Board not to issue decisions during the periods when its membership had fallen to two. ${ }^{61}$ But the dissent emphasized that the Board had decided nearly 500 cases during the three separate times when it had had only two members between 1935 and $1947 .^{62}$

\section{Intent and Purpose of the NLRA}

The majority's functional reasons for its interpretation focused the possibility that two members of the Board would decide policies that ought better be decided by a larger group. The majority rejected the Government's argument that the two-member reading served an overriding Congressional goal of Board efficiency and the importance of keeping the agency running during a difficult political stalemate, asserting that Congress could fix the problem by amending the statute and noting, via a citation to Robert's Rules of Order, that quorum requirements are "protection against totally unrepresentative action in the name of the body by an unduly small number of persons." ${ }^{63}$

The dissent, by contrast, faulted the majority for rendering the agency "defunct." ${ }^{64}$ The dissent began by emphasizing that the Board had been without a majority of the statutorily authorized members for over two years, a problematic situation for the agency and surely one not intended by Congress. Then the dissent offered two functional reasons to reject the majority's reasoning and allow two members of the Board to operate. The first, as the dissent pointed out, was the core of its disagreement with the majority: which is the lesser of two evils - to allow the Board to operate with less than a majority of its members for a protracted period of time or to shut the agency down entirely? This is really the core of the case, and it is the issue on which the Court offered much less than it should have in the way of reasons.

The general purpose underlying quorum rules - to ensure that a decision of a group of a body is representative of the whole body - is too general to answer the question. Since the majority accepted that the statute allows two members of the Board to act when the Board has at least three members, the Board has delegated its authority to a group of three, and the third member is not participating on account of a conflict or for another reason, the purpose of ensuring that the decision of the two-member group is representative of the views of the whole would be better served by

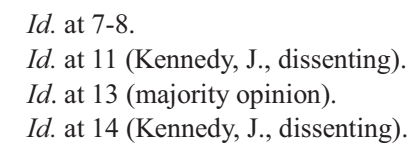


allowing a two-member group to act when the Board consists of only two because in that case the decision represents the views of 100 percent of the Board rather than only two-thirds of it. Similarly, the need to keep the agency operating when the confirmation process fails perhaps could result in just one remaining member deciding cases, which might be more than the dissent would tolerate. So, neither the specific legislative history, nor its (somewhat less specific) intent, nor its (even less specific) purpose answers the question whether the two-member Board can act. Fundamentally, the role of the courts when an agency's membership falls below a majority is the question posed but not answered in the case, and it raises hard questions about the role of courts, agencies, the President, and the Congress in matters of governance.

\section{THE DEFERENCE ARGUMENTS}

Neither of the Supreme Court opinions addressed a question that a number of the courts of appeals had considered: whether to defer to the Board's own interpretation of its powers under its enabling act. Both the Second Circuit and the Tenth Circuit concluded that, if the language of section 3(b) is ambiguous on the question of the two-member Board, it would be appropriate for courts to defer to the Board's interpretation of its own statute. $^{65}$ Under the framework of Chevron v. NRDC, ${ }^{66}$ the courts found section 3(b) to be ambiguous (the first step of the Chevron analysis) but found that the Board's interpretation of the statute was reasonable and therefore entitled to deference (under the second step of the Chevron analysis). These two cases found Chevron deference appropriate because the Board has authority to interpret its enabling statute (the NLRA), the Board had deliberated carefully over the meaning of the statute, and the Board sought and agreed to be bound by the Office of Legal Counsel's opinion as to the statute. ${ }^{67}$ Oddly, although Justice Stevens, who wrote the majority opinion in New Process Steel, was the author of Chevron, he did not address the question of Chevron deference.

There are good reasons for courts to defer to the agency's interpretation of its authority under its enabling act. The question whether to allow the agency to continue to function is fundamentally one of policy, and the NLRB may be in a better situation to understand and evaluate the pros and

65 Teamsters Local Union No. 523 v. NLRB, 590 F.3d 849, 850-52 (10th Cir. 2009); Snell Island SNF, LLC v. NLRB, 568 F.3d 410, 419-24 (2d Cir. 2009).

66 See generally Chevron USA Inc. v. Natural Resources Defense Council, 467 U.S. 837 (1984)

67 Teamsters, 590 F.3d at 851,; Snell Island, 568 F.3d at 415-16. 
cons of a shut-down as opposed to operation with a minority of members. ${ }^{68}$ Moreover, although the Court has never actually held that Chevron deference applies to agency interpretations of the agency's own jurisdiction, it has applied Chevron deference in several cases to disputes over the scope of an agency's jurisdiction. ${ }^{69}$

While there are reasons to conclude that Chevron deference is inappropriate, there are countervailing arguments for each. First, the Board's interpretation of its own authority to act was made in the first instance not as part of an adjudication but instead as a matter of its internal operations. ${ }^{70}$ On the other hand, the Board has adhered to its determination in the many adjudications in which its authority has been challenged, so its interpretation has been developed and articulated through formal adjudication."

Second, whatever the merits of Chevron deference in cases in which an agency interprets its enabling statute in most cases involving its own jurisdiction, the case for Chevron deference might be most problematic when an agency is determining its own survival. The employer and its ami$c i$ in New Process Steel objected to the practice of only two members deciding cases on the grounds that their views are not representative of those of the entire agency. ${ }^{72}$ On the other hand, because all four members of the Board decided to delegate authority to a group of three knowing that the authority would be exercised by only two members at the expiration of the recess appointments, the Board as a whole made the considered decision to allow members Liebman and Schaumber to keep the agency functioning. It may also have mattered to them that Liebman and Schaumber were appointed by presidents of different political parties and hold divergent views on labor policy, so they may have made the considered policy judgment that it was better for the agency and the law to allow those two to keep the agency operating than to allow the Board to stop rendering decisions.

68 See Pauly v. Bethenergy Mines, Inc., 501 U.S. 680, 696 (1991) ([insert present participal phrase] Chevron acknowledges that the resolution of ambiguity is often more a question of policy than law and that when Congress has delegated policymaking authority to an agency, the extent of judicial review of policy decisions should be limited). See generally RiCHARD J. PIERCE, JR., AdMinistrative LAW TREATISE $\$ 3.3$ (4th ed. 2002) (collecting cases on Chevron and policymaking).

69 See FDA v. Brown \& Williamson Tobacco Corp., 529 U.S. 120 (2000); Miss. Power \& Light Co. v. Mississippi, 487 U.S. 357 (1988); United States v. Riverside Bayview Homes, 474 U.S. 121 (1985); see also PIERCE, AdMINISTRATIVE LAW TREATISE $\S 3.5$ at 157 (arguing that Chevron deference should apply to agency interpretations of its jurisdiction).

70 See Christensen v. Harris County, 529 U.S. 576, 587 (2000) (Chevron deference applies to formal adjudication and notice-and-comment rulemaking but not to opinion letters, policy statements, agency manuals, and enforcement guidelines because the latter "lack the force of law").

71 Brief for the National Labor Relations Board at 6, n.7, New Process Steel, L.P. v. NLRB, No. 08-1457, slip op. (U.S. June 17, 2010).

72 Brief for Petitioner New Process Steel, L.P. at 33, New Process Steel, No. 08-145; see also Brief for Amicus Curiae Chamber of Commerce at 20, New Process Steel, No. 08-1457. 
Third, the Board explicitly relied on the advice of OLC, not solely on its own reading of the statute, and OLC opinions do not get Chevron deference. $^{73}$ On the other hand, the Board made clear both before it sought OLC's opinion and afterward that it had reached its own judgment about the propriety of the delegation.

Finally, on the three occasions since 1947 when the Board's membership has fallen below three, the Board has declined to decide cases. This has been argued to mean that the Board's interpretation of its powers is not entitled to Chevron deference because it is not a consistently held position of the agency. ${ }^{74}$ On the other hand, the Board may have believed in each of those instances that the vacancies would be brief and that labor policy would be best served by waiting for new members to be confirmed. In this instance, by contrast, having watched President Bush fail to gain confirmation for his nominees and knowing that the occupant of the White House was changing and that nominations might be very slow in coming, the Board might have decided that labor policy would be better served by continuing.

Reasonable minds can differ on the language, legislative history and Chevron deference analyses. In this case, the vast majority of judges rejected the majority's reading, which makes the majority's reliance on plain language particularly unpersuasive. While it is of course true that all that matters in the end is that five of the nine judges on the Supreme Court agreed with one reading, it does a disservice to the cause of reasoned decisionmaking to pretend that the language, history, or purpose of the statute decide the case when the majority of judges who considered the very arguments that the majority opinion makes rejected them.

What the decision reflects is the dominance of the highly formalist style of legal reasoning that treats issues as if they were resolvable based solely on a close reading of the text of a statute or the Constitution when what really divides the judges are underlying issues about substantive policy or separation of powers. This divide between the formalism of putatively textual or originalist modes of statutory and constitutional interpretation and functionalist modes appeared in other cases this Term, particularly Free Enterprise Fund v. Public Company Accounting Oversight Board, in which five justices, in an opinion by Chief Justice Roberts, struck down a provision of the accounting reforms instituted by Sarbanes-Oxley. ${ }^{75}$ The majority

73 Brief for the National Labor Relations Board, supra note 71 at 4-5.

74 Brief for Petitioner New Process Steel, LP, at 5, New Process Steel, No. 08-1457; Brief for Amicus Curiae Chamber of Commerce at 15, New Process Steel, No. 08-1457.

75 Free Enter. Fund v. Pub. Co. Accounting Oversight Bd., No. 08-861, slip op. at 33-34 (U.S. June 28, 2010). 
held that the provision allowing the Securities Exchange Commission to remove members of the Public Company Accounting Oversight Board only for cause violated separation of powers because it deprived the President of the power to remove them at will. Justice Breyer, joined in his dissent by Justices Stevens, Ginsburg, and Sotomayor, faulted the majority for, among other things, adopting a reading of Executive power that ignores the practical realities of the administrative state and called for a functional approach to addressing the powers of independent agencies and commissions.

There are a number of parallels between the result and reasoning in New Process Steel and Free Enterprise Fund. First, the conservative majority in both cases determined that an independent agency was unlawfully constituted because of a defect in the machinery of the appointments of its five members. Although in New Process Steel the source of the defect was statutory and in Free Enterprise Fund the problem was constitutional, in both cases the conservative majority held that the agency could not properly operate. Second, in both cases the majority reasoned to the result by relying on a formalist style of reasoning that purported to be commanded by the text of the statute or the constitution, rejecting the dissent's argument that the majority's interpretation would wreak havoc with the sensible operation of the administrative state. And, third, in both cases the majority's decision raised but did not address a host of difficult issues about its scope and the possible invalidity of a number of agency actions, thus leaving the lawyers for the affected government agencies with a daunting task of figuring out implications of the decision. In both cases, the dissent insisted that greater weight should be given to practical considerations such as the need for agencies to function in an imperfect world, and in both cases the call for functionalism garnered only four votes.

\section{FUNCTIONAL ARGUMENTS}

While the problems with the confirmation process are undoubtedly political - the President and the Senate (either a majority or a minority) cannot resolve their differences on labor policy enough to nominate or confirm members that are palatable to their policy adversaries, it is too facile to say that the solution should be political. Chief Justice Roberts suggested at the end of the oral argument in New Process Steel that the solution may be recess appointments, and President Obama took the hint by making two recess appointments just a day or two after the argument, having previously said he would not use recess appointments to staff the Board. Justice Stevens' majority opinion said that Congress "can easily" allow the Board

76 Id. at 18 (Breyer, J., dissenting). 
to operate with only two members, ${ }^{77}$ but anyone even remotely familiar with labor law knows that amending the NLRA is not easy. Every single change to the statute has been filibustered since 1974. Sixty-three percent of appointments to the NLRB since 1988 have been recess appointments. The problem is that recess appointments serve short terms, and it is difficult for the Board to decide controversial cases or to contemplate rule-making or other regulatory reform when its membership is constantly in flux or at risk of departure.

The underlying issues raised by the New Process Steel case go to the heart of the administrative state. Now that we know that Congress or the President can shut an agency down simply be declining to nominate or confirm new members, will that power be exercised? By whom - a President hostile to the goals of the NLRA? A Senate minority determined to use its filibuster power? A Senate majority at odds with the President? How does the recent trend toward filling the agency with recess appointments affect its functioning? Was the failure of Congress to confirm nominees and the President to use recess appointments facilitated by the NLRB's willingness to continue to operate with only two members? Would courts help the nomination process by forcing the Senate and the President to choose between confirming nominees and total shut-down? Or would allowing the failure of the confirmation to shut the agency down give a form of heckler's veto that would ultimately damage the administrative state? To what extent is this problem unique to labor agencies or other highly-politicized agencies? To what extent has this problem gotten worse because of an increase in holds and filibusters? Does the ability to block a nomination, or the refusal to nominate a successor, allow the Senate or the President a kind of de facto repeal of the enabling statute? If so, is there anything wrong with that, or at least wrong enough that the courts should address it? Full consideration of these issues must await another article. What follows are some preliminary thoughts.

\section{A. Congress, the Executive and the Functioning of Agencies}

As is well known, the ordinary confirmation process for independent agencies is, as for the judiciary and other cabinet-level and high-level positions, presidential nomination subject to the advice and consent of the Senate. When that process fails, recess appointments may be made under the Vacancy Clause, U.S. Const. art. II, $\S 2$ : "The President shall have Power to fill up all Vacancies that may happen during the Recess of the Senate,

77 New Process Steel, No. 08-1457, slip op. at 14. 
by granting Commissions which shall expire at the End of their next Session." With respect to some agencies (not the NLRB), the Vacancies Act authorizes the President to direct an officer or employee of an agency to perform the functions and duties of an office that becomes vacant on a temporary or acting basis.

The nomination and confirmation process has grown lengthier in recent decades with the result that more vacancies exist at the senior level in agencies. ${ }^{79}$ The length of the confirmation process and the likelihood that nominations will fail have been particularly great in highly politicized areas of law. ${ }^{80}$ This is particularly true with respect to the NLRB, where the political stalemate over nominations has grown worse in the past thirty years. According to Richard Block, there were no recess appointments to the NLRB before 1980, but 63 percent of nominations to the Board between 1988 and 2008 were by recess appointment. Relatedly, no nominations to the Board died without action in the Senate before 1968, ten percent did not get through the Senate between 1968 and 1987, and over a quarter failed in the Senate between 1988 and $2008 .^{81}$

Much has been written lately on the Senate confirmation process, particularly as applied to judicial nominations. Several factors are frequently said to account for the increase in time and rancor in the confirmation process. One factor is that, as the size of the federal bureaucracy has grown, the minority party has realized the power it can exercise by blocking nominations to government agencies. A second factor is that the Democratic and Republican parties have become increasingly polarized on a number of issues, as moderates are scarce in both parties and cross-over votes have become rare on a host of issues, and labor relations is one of the issues on which the parties are very divided.

Some have attributed the failure of the confirmation process to the contemporary tendency of the White House and the Senate to treat nominations as a "package." " While this is not true over the longer term of NLRB nominations, it is true with respect to the recent nominations by both President Obama and President Bush. The 27-month vacancies was the product

78 5 U.S.C. $\S \S 3345-3349 \mathrm{~d}(2006)$.

79 Anne Joseph O'Connell, Vacant Offices: Delays in Staffing Top Agency Positions, 82 S. CAL. L. REV. 913, 914, 920 (2009).

80 See id. at $920-21$.

81 Susan J. McGolrick, Professor/Arbitrator Calls NLRA 'Pretty Sick,' Calls for Substantive, Procedural Fixes, 112 DAILY LABOR REPORT B-1 (2009).

82 Id. (attributing to former Board member, Sarah Fox, the view that the appointment process is designed to allow gradual change in the agency by replacing one member every year; that the "package" system politicizes the process by treating nominees as representing the interests of labor or management; and that the package system contributes to long vacancies). 
of a stand-off between the White House and the Senate over confirmation of the three new members. The Democratic Senate majority refused to confirm the Republican choice of member if the Republican Senate minority continues to filibuster the Democratic choice. President Obama announced early in his term that he would not use recess appointments when the Senate refuses to vote on his nominees, in part because President Bush angered Senators by using recess appointments for seven of his nine nominees to the NLRB. This stand-off is not a unique situation involving this President and this majority and minority in the Senate. Toward the end of George W. Bush's second term as president, the Democratic Senate majority refused to confirm his slate of nominees to the Board and even refused to recess to prevent him from making recess appointments (not only to the NLRB but to other agencies as well). ${ }^{8}$

The willingness of the Senate to block agency appointments may not be the same as between Democrats and Republicans. When an agency is short on members, the inability of remaining members to act operates as a de facto elimination of the agency's regulatory authority. On a systemic basis, the failure of an agency to meet its quorum rule serves the interests of those resisting regulatory intervention. As one commentator has observed, in the case of the FTC and its role reviewing mergers, this gives greater weight to a political position that favors acquisitions. ${ }^{84}$ As applied to the NLRB, this generally means that those who favor elimination of NLRB enforcement of federal labor law have less to lose by blocking nominations than those who support NLRB enforcement. Generally, this means that Republicans will be more willing to either nominate candidates that they know will be extremely controversial in the Senate or to refuse to confirm those whom they dislike than Democrats are because Democrats are more likely to conclude that even a conservative, pro-management Board is better than no Board at all. Moreover, as scholars have complained for decades, delay has an insidious effect of weakening the NLRA's election machinery and unfair labor practice remedies, such that delay generally helps employers and harms unions and wrongfully discharged employees.

In sum, delay or failure of the confirmation process is not likely to harm both labor and management equally. Delay or agency shut-down is more likely to harm labor, which means delay is more likely to be a tool used by the interests of management.

83 Edwin S. Hopson, NLRB Member Confirmation Battles - January 2001 - January 2009, WYATT EMPLOYMENT LAW REPORT (Feb. 15, 2010), http://wyattemployment.wordpress.com/2010/02/ 15/nlrb-member-confirmation-battles/.

84 Falls, supra note 28, at 711. 
B. The Role of Courts in Invalidating Agency Action Based on Structural Objections to the Agency's Composition

An enduring question is what role courts should play when failures of the nomination and confirmation process threatens to prevent an agency from acting at all. The Supreme Court did not address this issue, but it is an important and recurring one. There are a few instances in which the issue has arisen in the past, and those cases are examined below for the light they shed on the issues that the Supreme Court neglected in New Process Steel.

In Assure Competitive Transportation v. United States, an organization of common carriers (ACT) challenged a decision of the Interstate Commerce Commission granting an application of a trucking company seeking authorization to transport general commodities in the Midwest. ${ }^{85}$ ACT alleged that the ICC lacked authority to act because it had only five of the statutory eleven members. ACT offered evidence "tending to show that" the President had intentionally refused to appoint Commissioners, and sought invalidation of all ICC orders from June 30, 1978, when the Commission's membership fell to five, to the following year. ${ }^{86}$ The Seventh Circuit rejected the contention, finding that under the enabling statute a quorum of the ICC is a majority of the existing Commission, not a majority of the total authorized members. ${ }^{87}$ ACT also argued that the Commission's action was unconstitutional because the president had deliberately failed to appoint replacements, thus violating the appointments clause (Art. II, $\S 2$, cl. 2), the take care to faithfully execute the law clause (Art. II, § 3, cl. 4), and the separation of powers (in particular, the provision of Art. I, § 8, cl. 3 providing that Congress regulates commerce). ${ }^{88}$

The court rejected the constitutional challenge to the power of the ICC, explaining that the five existing commissioners were duly appointed by the President with the concurrence of the Senate and were thus validly exercising power and that the enabling statute specifically provided that vacancies would not affect the power of the Commission to act. ${ }^{89}$ The court then continued:

The only arguable illegality is on the part of the President, who may be, as alleged, intentionally or unreasonably failing to appoint a full complement of Commissioners. In so withholding his power of appointment, ACT asserts, the President is effectively legislating a

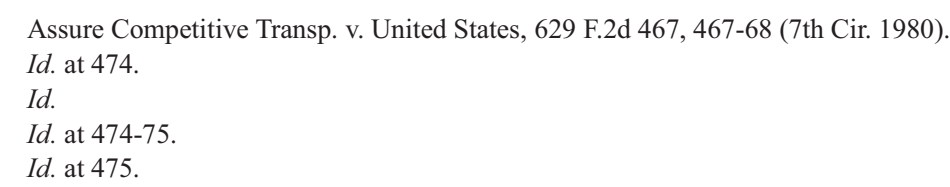


different size Commission than the eleven member Commission prescribed by Congress. . . .

We need not be detained by the complex issues that would involve us here were this a proper action alleging that the President was acting illegally and asking that he be compelled to make the requisite number of appointments to the Commission. This is not a mandamus action where the President has been made a party defendant. . . . We express no opinion as to the likelihood of success of a mandamus action."

It's a large understatement to characterize as "complex" the issues that would confront a court deciding whether it has the power to wade into the confirmation process and what remedy to order even if it decided that a failure to nominate or to confirm members to the Board were done with the express purpose of preventing the agency from acting.

Even though the Court concluded that the NLRB cannot act with only two members, it does not follow that the NLRB's actions since January 2008 have become invalid. In a past high-profile circumstance when the Supreme Court found that another government agency lacked the authority to act because of structural flaws in its composition, the Court allowed the agency to keep acting while Congress designed and enacted a new structure. In Northern Pipeline Construction Co. v. Marathon Pipe Line Co., the Court found that the bankruptcy courts as then constituted violated Article III of the Constitution because they vested in non-Article III courts functions that Congress could not properly vest in such courts. ${ }^{91}$ Rather than invalidate all the handiwork of the bankruptcy courts in the five years between the enactment of the Bankruptcy Act and the Court's decision, however, the Court decided to apply its decision prospectively only and, moreover, it stayed its decision for several months to "afford Congress an opportunity to reconstitute the bankruptcy courts or to adopt other valid means of adjudication, without impairing the interim administration of the bankruptcy laws." That is, not only did the Court hold that the cases that the bankruptcy courts had decided were validly decided, it also empowered them to continue in business for another several months even though the Court had decided that they were unconstitutionally exercising power. At the end of the year, Congress had not fixed the problem, but the Supreme Court denied the government's application to further extend the stay. ${ }^{93}$

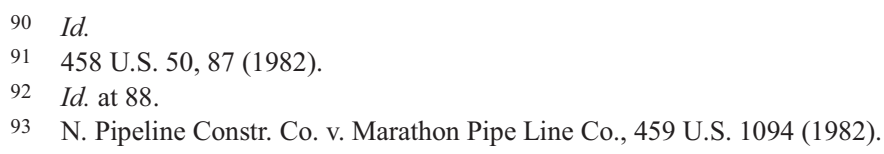


Similarly, in Buckley v. Valeo, the Court held that the Federal Elections Commission was unconstitutionally constituted because Congress retained control over the appointment of some members and thus violated the separation of powers principle that executive powers can be exercised only by agencies whose members are appointed by the executive. ${ }^{94}$ But the Court explicitly held that the unconstitutionality of its membership was not a basis for invalidating its past acts, and indeed stayed the Court's decision for thirty days to allow Congress to reconvene the Commission in a manner that would meet the Court's new separation of powers test. ${ }^{9}$

There are a few precedents in addition to those described above involving circumstances when an agency was effectively prevented from acting because of failures to nominate or confirm members: Federal Election Commission in 2008; ${ }^{96}$ Consumer Product Safety Commission in $2006 ;{ }^{97}$ Federal Mine Safety and Health Review Commission in $2004 ;^{98}$ and Occupational Safety and Health Review Commission in 1987-88. ${ }^{99}$ The approach to each differed. In 2008, when CPSC lost quorum, Congress enacted a temporary provision allowing two members of the CPSC to operate for six months. ${ }^{100}$ When OSHRC fell to just one member in 198788 , the lone remaining member had the option under the enabling statute of declining to review administrative law judge decisions thus allowing the decision to become final and the parties to see review in the courts. ${ }^{101}$

94 Buckley v. Valeo, 424 U.S. 1, 142 (1976).

95 Id.

96 FEC, Fiscal year 2010 Congressional Justification \& Performance Budget at 4 (May 7, 2009), available at www.fec.gov/pages/budget/fy2010/FY_2010_CJ_Bud_05_07final.pdf.

97 Consumer Product Safety Commission, 2009 Performance Budget Request at 8 (Feb. 2008), available at www.cpsc.gov/cpscpub/pubs/reports/2009plan.pdf.

98 See Federal Mine Safety and Health Review Commission, Justification of Appropriation Estimates for Committee on Appropriations FY 2006 at 2, available at www.fmshrc.gov/plans/ fy06budget.pdf.

99 See McLaughlin v. Union Oil Co. of Cal., 869 F.2d 1039, 1041-43 (7th Cir. 1989).

100 See 15 U.S.C. $\$ 2053$ (d) (2006) ("No vacancy in the Commission shall impair the right of the remaining Commissioners to exercise all the powers of the Commission, but three members of the Commission shall constitute a quorum for the transaction of business, except that if there are only three members serving on the Commission because of vacancies in the Commission, two members of the Commission shall constitute a quorum for the transaction of business, and if there are only two members serving on the Commission because of vacancies in the Commission, two members shall constitute a quorum for the six month period beginning on the date of the vacancy which caused the number of the Commission members to decline to two.").

101 See McLaughlin, 869 F.2d at 1041-43 (rejecting the contention that OSHRC's failure to review the ALJ decision denied a party of a right to full administrative review and declining to remand the case to the agency, which by the time of the court of appeals decision had a quorum, on the grounds that the public safety implications of the case - which involved an explosion at an oil refinery - made it undesirable to remand the case to the "fragile agency"). 
Congress has authorized members to continue to serve on a commission until a replacement is nominated and confirmed. For example, members of the EEOC "continue to serve until their successors are appointed and qualified," ${ }^{102}$ as do Commissioners of the Federal Trade Commission. ${ }^{103}$ Similarly, members of the Commodity Futures Trading Commission hold office "for a term of five years and until his successor is appointed and has qualified." 104 Congress has permitted agencies to temporarily fill vacancies with administrative law judges. As noted above, however, many familiar with the repeated failed efforts to amend the NLRA are skeptical that even this fix would pass through Congress.

One issue on which the Court probed the parties at oral argument but that it did not adequately discuss in its opinion is which of the NLRB's functions became invalid during the period in which it had only two members. It is revealing that none of the parties in the Supreme Court were able (or at least willing) to discuss authoritatively which of the NLRB's functions would have to cease if the Board cannot act with two members (or when its membership falls to one). As noted above, the majority noted in a footnote that its conclusion "does not cast doubt on the prior delegations of authority to nongroup members, such as the regional directors or the general counsel." This seems to suggest that the majority thought the delegations to the regions and the general counsel were not affected by the vacancies. Yet, the majority continued, "The latter implicates a separate question that our decision does not address," which suggests only that the Court was not deciding whether those delegations were valid, and that later litigation would determine that issue. Or perhaps that the delegations could be challenged in the District of Columbia, because the D.C. Circuit had said the delegations were invalid, but not in the other five circuits which had found all the delegations valid. ${ }^{105}$

10242 U.S.C. $\$ 2000 \mathrm{e}-4$ (a) (2006).

10315 U.S.C. $\S 41$ (2006).

1047 U.S.C. $\$ 2(a)(2)(A)($ ii) (2006).

105 If the validity of delegations other than to Chairman Liebman and Member Schaumber is an open issue, a number of questions arise besides just the obvious ones having to do with whether the Regional Attorneys and the General Counsel have the authority to seek injunctions under section 10 . For example, the next time the Board falls to two, if ALJs continue to decide cases, but there is no Board to review the decisions, can the respondent decline to comply and, since Board decisions are not selfenforcing, does that mean that effectively there is no enforcement? 


\section{CONCLUSION}

The core question at issue in New Process Steel v. NLRB is whether an agency can function when its membership falls below a majority of the statutorily authorized members when Congress has not clearly specified what should happen. Although some enabling acts clearly provide for agency functioning in the absence of confirmation of new members, the NLRA does not. Section 3(b) of the NLRA addresses the issue, but it does so ambiguously. Its four clauses - a provision allowing delegation of authority to three members, a provision stating that vacancies shall not affect the power of the remaining members to exercise the powers of the Board, a clause stating that a quorum is three members, and a clause creating an exception to the general quorum clause providing that a quorum of a delegee group is two - leave room for argument as to whether the three-member quorum clause trumps the vacancy clause and the final exception, or whether the vacancy clause and the final exception trump the general threemember quorum.

The four justices and fifteen courts of appeals judges, as well as the four members of the Board, who decided the Board could keep functioning did so not because the language, history, or purpose of section 3(b) was plain, but rather because they thought it does not make functional sense to allow a failure of the confirmation process to operate as a kind of de facto deregulation. Likewise, the five justices and three court of appeals judges who reached the contrary position did so because they believed that declaring the Board inoperative was a less destructive outcome than allowing two members of a five-member agency to decide cases the next time Congress and the President cannot agree on nominees. In various places, the $\mathrm{Su}-$ preme Court majority and dissent alluded to the underlying functional justifications for their decisions, but they did not explore or defend them. This is an instance in which the formalism of statutory interpretation in administrative law not only does not explain results, it does not even adequately justify them. New Process Steel represents a lost opportunity for the Court to discuss explicitly what role it and the courts of appeals should play in the administrative state when the intensely political process of agency composition, nomination, and confirmation fails. For that, we will have to wait. 